\title{
POLITIK HUKUM DAN KELEMAHAN UNDANG-UNDANG NOMOR 26 TAHUN 2000 TENTANG PENGADILAN HAK ASASI MANUSIA
}

\author{
Oleh \\ Bambang Sucondro*)
}

\section{Abstrak}

Berbagai pelanggaran hak asasi manusia di Indonesia hingga kini dianggap masih belum tuntas diselesaikan. Padahal dari segi regulasi, Indonesia telah memiliki payung hukum berupa Undang-Undang Nomor 26 Tahun 2000 tentang Pengadilan Hak Asasi Manusia. Atas hal itu, maka menarik untuk dikaji dari segi politik hukum dengan memfokuskan pada dua pertanyaan: 1) politik hukum apa yang melatarbelakangi dibentuknya Undang-Undang Nomor 26 Tahun 2000 sehingga dianggap masih memiliki kelemahan?; 2) bagaimana langkah hukum yang harus dilakukan dalam menyempurnakan materi muatan UU No. 26 Tahun 2000?. Penelitian ini merupakan jenis penelitian yuridis-normatif yang menggunakan pendekatan perundang-undangan. Hasil dari penelitian, menunjukan bahwa politik hukum dibentuknya UU No. 26 Tahun 2000 dalam rangka merespon tuntutan dalam negeri dan internasional yang meminta agar pelanggaran hak asasi manusia segera diselesaikan. Selain itu, juga dalam rangka menghindarkan negara Indonesia dari ancaman penyelesaian pelanggaran hak asasi manusia melalui peradilan internasional. Mengingat pembentukannya hanya didasarkan pada pertimbangan pragmatis, maka terdapat banyak kelamahan dalam undang-undang tersebut sehingga penting untuk dilakukan penyempurnaan dengan melakukan perubahan.

\section{Kata Kunci : Hak Asasi Manusia, Pengadilan, Politik Hukum, dan Undang-Undang}

\section{A.PENDAHULUAN}

Pergulatan pemikiran tentang Hak Asasi Manusia (HAM) sesungguhnya bukanlah wacana baru dalam diskursus politik dan ketatanegaraan di Indonesia. Sejak kemerdekaan, para perintis bangsa ini telah memercikkan berbagai gagasan guna memperjuangkan harkat dan martabat manusia yang lebih baik. ${ }^{1}$ Oleh karenanya, menjadi

1 Jimly Asshiddiqie, Pengantar Ilmu Hukum Tata Negara. Jilid 1. (Jakarta: Sekretariat Jenderal dan Kepaniteraan Mahakamah Konstitusi, 2006 ), hlm. 85. Lihat juga dalam Rhona K.M.

*) Penulis adalah Dosen Fakultas Hukum Universitas Trisakti Jakarta hal yang lumrah jika berbagai tuntutan atas tiap-tiap pelanggaran HAM secepatnya harus diselesaikan tanpa tebang pilih. Hal ini juga yang kemudian melatar belakangi berdirinya Komisi Nasional Hak Asasi Manusia (KOMNAS HAM) di Indonesia. ${ }^{2}$ Pada mulanya pembentukan komisi ini memang masih disambut skeptic,

Smith, Hukum dan Hak Asasi Manusia, (Yogyakarta, PUSHAM UII, 2008), hlm. 277.

2 R. Wiyono, Pengadilan Hak Asasi Manusia Di Indonesia, (Jakarta: Kencana Prenada Media Group, 2006), hlm. 3 . 
namun bertahap lembaga ini pun mulai memperoleh kepercayaan masyarakat. ${ }^{3}$

Pembentukan KOMNAS HAM sesungguhnya sejalan dengan tujuan yang termaktub dalam Pasal 44 Ketetapan Majelis Permusyawaratan Rakyat (TAP MPR) Noor XVII/MPR/1998 tentang Hak Asasi Manusia. 4 Guna memperoleh penegakan HAM yang efektif di Indonesia, kemudian juga di UndangUndangkan Nomor 39 tahun 1999 tentang HAM. Akan tetapi mengingat terdapat berbagai kelemahan yang ada, maka pada perkembangan selanjutnya ditetapkan tentang Pengadilan Hak Asasi Manusia. Pada selanjutnya Perpu tersebut di ajukan ke DPR namun di tolak sehingga kemudian Pemerintah mengajukan Rancangan UndangUndang (RUU) ${ }^{5}$. Inisiatif Pemerintahn

3 Saafroedin Bahar, Konteks Kenegaraan Hak Asasi Manusia, (Jakarta: Sinar Harapan, 2002), hlm. 370-371

4 Pasal 44 menerangkan bahwa untuk menegakkan dan melindungi hak asasi manusia sesuai dengan prinsip negara hukum yang demokratis, maka pelaksanaan hak asasi manusia

5 Alasan penolakan Perpu tersebut sebagai berikut: (1). Secara konstitusional pembentukan perpu tentang pengadilan HAM dengan mendasarkan pada Pasal 22 ayat 1 Undangundang Dasar 1945 yang berbunyi "dalam hal ihwal kegentingan yang memaksa", yang dijadikan dasar untuk mengkualifikasikan adanya kegentingan yang memaksa dianggap tidak tepat; (2). Subtansi yang diatur dalam Perpu tentang Pengadilan HAM masih terdapat kekurangan atau kelemahan antara lain, sebagai berikut :a. Kurang mencerminkan rasa keadilan karena ketentuan dalam perpu tersebut tidak berlaku surut (retroaktif), sehingga pelanggaran HAM yang berat yang dilakukan sebelum Perpu ini disahkan menjadi undang- tersebut akhirnya membuahkan hasil dengan lahirnya Undang-Undang Nomor 26 tahun 2000 tentang Pengadilan Hak Asasi Manuisia

Adanya Undang-Undang Nomor 26 tahun 2000 tersebut, diharapkan dapat menjadi dasar yang penguat dalam mewujudkan kepastian hukum dan keadilan dalam proses penegakan HAM di Indonesia. Namun sejauh ini, nampaknya persoalan penegakan HAM masih belum tuntas seiring dengan belum selesainya kasus-kasus besar pelangatan HAM, seperti kasus Talangsari, Semanggi dan Trisakti.

Kondisi tersebut, tentu menimbulkan tanya apakah sejumlah instrument hukum penegakan HAM, khususnya Undang-Undang Nomor 26 tahun 200 tidak efektif sebagai jalan penyelesaian HAM di Indonesia.

Di samping itu, Indonesia sebenarnya telah meratifikasi Konvenan Internasional tentang Hak-Hak Ekonomi, Sosial dan Budaya melalui Undang Undang Nomor 11 tahun 2005 tentang Ratifikasi Konvensi Internasional Ekonomi, Sosial dan Budaya. Nanum

undang tidak tercakup pengaturannya; b. Masih terdapat ketentuan yang dinilai menyimpang dari ketentuan yang diatur dalam konvensi tentang pencegahan dan penghukuman kejahatan genosida tahun 1948 dan tidak sesuai dengan asas-asas hukum yang berlaku; c. Masih menggunakan standar konvensional, yakni dengan mendasarkan pada KUHP yang hanya membatasi tuntutan pada personal sehingga tidak mampu menjangkau tuntutan secara lembaga; d. Masih terdapat subtansi yang kontradiktif dan berpotensi untuk berbenturan atau overlapping dengan hukum positif. Lihat Zainal Abidin, Pengadilan Hak Asasi Manusia Di Indonesia, (Jakarta: Lembaga Studi dan Advokasi Masyarakat, 2007), hlm. 4. 
sayangnya, ketentuan dalam ratifikasi belum terakomodir di dalam UndangUndang nomor 26 tahun 200 sehingga apabilan terjadi pelanggaran HAM berbasis ekonomi, sosial dan Budaya tidak dapat terselesaikan. Menurut Muladi 6, meskipun Undang-Undang tersebut banyak mengadopsi normanorma hukum internasional, seperti International Crime Court (ICC), namun hanya mengambil sebagian dan pengadopsiannya tidak sistematis sehingga banyak menghilangkan hal-hal yang penting. Hal-hal penting yang tidak terambil, seperti tidak masuknya kejahatan perang, perlindungan saksi yang tidak maksimal dan hukum acaranya yang masih menggunakan hukum acara Kitab Undang-Undang Hukum Pidana.

Berdasarkan permasalahan di atas, maka penting untuk dijawab mengapa Undang-Undang Nomor 26 tahun 200 yang diproyeksikan sebagai jalan pertama dan terakhir penyelesaian HAM berat hasilnya teradapat banyak kelemahan? Hal itu menjadi penting, mengingat sebagai intrumen hukum, seharusnya Undang-Undang Nomor 26 tahun 2000 dapat menjadi solusi dalam penyelesaian pelanggaran HAM di Indonesia secara baik.

\section{Metode}

Penelitian ini merupakan penelitian yuridis-normatif, yaitu penelitian yang memusatkan perhatian pada kajian tentang norma-norma hukum yang terdapat dalam peraturan perundangundangan. Adapun sumber data yang digunakan, yaitu sumber data sekunder yang terdiri dari bahan hukum

6 "Muladi: Peradilan HAM Punya Banyak Kelemahan",https://nasional.tempo.co / read/38678/muladi-peradilan-hampunya-banyak-kelemahan. Akses, 01 Februari 2019. primer, sekunder dan tertier. Sementara, pendekatan yang digunakan adalah pendekatan perundang-undangan.

\section{Konsepsi Politik Hukum}

Moh. Mahfud MD menyatakan, politik hukum merupakan kristalitsasi dari kehendak kehendak politik yang saling bersaing dalan pemberlakuan hukum, sehingga latar belakang politik tertentu melahirkan hukum dengan karakter tertentu 7 . Politik hukum, adalah arahan atau garis resmi yang dijadikan dasar pijak dan cara untuk membuat dan melaksanakan hukum dalam rangka mencapai tujuan bangsa dan negara. Dapat dikatakan juga bahwa politik hukum merupakan upaya menjadikan hukum sebagai proses pencapaian tujuan negara ${ }^{8}$.

Bernard L. tanya menegaskan, politik hukum lebih mirip sebagai suatu etika yang menuntut agar suatu tujuan yang dipilih harus dapat dibenarkan oleh akal sehat yang dapat diuji dan cara yang ditetapkan untuk mencapainya haruslah dapat di tes dengan kriteria normal ${ }^{9}$. Tepatnya politik hukumn lebih bisa dianggap sebagai seni untuk membuat hukum (the art of making law) yang berangkat

${ }^{7}$ Definisi seperti ini diakui oleh Moh. Mahfud MD berakar pada definisi politik hukum yang dikemukakan oleh Padmo Wahjono, meskipun definisi ini agak berbeda dengan kenyataan yang ada dalam bukunya Politik Hukum di Indonesia yang menyatakan bahwa politik hukum merupakan legal policy (kebijakan) resmi tentang hukum yang akan diberlakukan baik dengan pembuatan hukum baru maupun dengan penggantian hukum lama, dalam rangka mencapai tujuan negara Moh. Mahfud MD, Politik Hukum di Indonesia, Rajawali Press, Jakarta, 2011, hlm. 1

8 Moh. Mahfud MD, Membangun Politik Hukum, Menegakkan Konstitusi..., Loc.it

9 Bernard L. Tanya, Politik Hukum: Agenda Kepentingan Bersama, (Yogyakarta: Genta Publishing), 2011, hlm. 3. 
dari dunia Sollen menuju kedalam dalam dunia sein. Sollen karena apa yang diinginkan politik hukum tidaklah terikat pada yang ada, dia bersifat seharunya (ought to). Bersifat sein karena hal yang ought to tadi sebisa mungkin harus terpahami di dalam kehidupan yang nyata sebagaimana sudah dikatakan bahwa hukum adalah untuk manusia ${ }^{10}$.

Kemudian Padmo Wahjono memandang bahwa politik hukum adalah kebijakan dasar yang menentukabn arah, bentuk maupun isi hukum yang akan dibentuk ${ }^{11}$. Pengertian ini kemudian diperjelas bahwa politik hukum adalah kebijakan penyelenggara negara tentang apa yang dijadikan kriteria untuk menghukumkan sesuatu yang di dalamnya mencakup pembentukan, penerapan penegakan hukum ${ }^{12}$. Tidak jauh berbeda dengan apa yang dikatakan oleh Padmo Wahjono, Sujtipto Rahardjo mendefinisikan politikm hukum sebagai aktifitas memilih dan cara yang hendak dipakai untuk mencapai tujuan social dengan hukum tertentu yang cakupannya meliputi jawaban atas beberapa pertanyaan mendasar, yaitu :

a. Tujuan apa yang hendak dicapai melalui sistem yang ada

b. Cara-cara apa dan yang mana yang dirasa paling baik untuk dipakai dalam mencapai tujuan tersebut.

c. Kapan waktunya dan melalui cara bagaimana hukum itu perlu diubah, dan;

10 ibid., hlm. 4.

11 Padmo Wahjono, Indonesi Negara Berdasarkan atas Hukum, Ghalia Indonesia, Jakarta, 1986, hlm. 1.

12 Padmo Wahjono, Menyelisik Proses Terbentuknya Peraturan PerundangUndangan, dalam Moh. Mahfud MD, Membangun Politik Hukum, Menegakkan Konstitusi, (Jakarta: PT Raja Grafindo), 2010, hlm. 13. d. Dapatkah suatu pola yang berlaku dan mapan dirumuskan untuk membantu dalam memutuskan pola pemililhan tujuan serta untuk mencapai tujuan tersebut dengan baik $^{13}$.

Sunaryati Hartono, secara eksplisit merumuskan arti politik hukum sebagai alat dan bahwa secara praktis politik hukum merupakan alat suatu sarana dan langkah yang dapat digunakan oleh Pemerintah untuk menciptakan sistem hukum nasional untuk mencapai cita-cita bangs dan tujuan negara ${ }^{14}$. Kemudian, hakim Garuda Nusantara mendefinisikan politik hukum sebagai legal policy atau kebijakan hukum yang hendak diterapkan atau dilaksanakan secara Nasional oleh pemerintahan untk menciptakan sistem hukum Nasional untuk mencapai cita-cita bangsa dan tujuan negara. Kemudian, Hakim Garuda Nusantara mendefinisikan politik hukum sebagai legal Policy atau kebijakan hukum yang hendak diterapkan atau dilaksanakan secara nasional oleh suatu pemerintah negara tertentu yang meliputi : 1) pelaksanaan secara konsisten ketentuan hukum yang telah ada; 2) pembangunan hukum-hukum baru; 3) penegawan fungsi lembaga penegak hukum serta pembinaan para anggotanya; 4) peningkatan kesadaran

13 Sadjipto Raharjo, Ilmu Hukum, Bandung, Bandung: Citra Adtya Bhakti, 1991, hlm. Coba bandingkan dengan Abdul Hakim G Nusantara, "Politik Hukum Nasional", Makalah pada Karya Latihan Bantuan Hukum (Kalabahu), YLBHI \& LBH Surabaya, September 1985, dalam Imam Syaukani dan A. Ahsin Thohari, DasarDasar Politik Hukum, Raja Grafindo Persada, Jakarta, 2006, hlm. 30-31.

${ }^{14}$ Moh. Mahfud MD, Membangun Politik Hukum, Menegakkan Konstitusi..., Op. Cit, hlm. 15. 
hukum masyarakat menurut persepsi elite pengambilan kebijakan ${ }^{15}$.

\section{B. PEMBAHASAN}

\section{Politik Hukum Pembentukan Undang-Undang Nomor 26 Tahun 2000 tentang Pengadilan Hak Asasi Manusia}

Istilah pengadilan HAM untuk pertama kalinya disebutkan secara formil dalam Bab IX tentang Pengadilan Hak Asasi Manusia Pasal 104 ayat (1), (2) dan (3) Undang-Undang Nomor 39 Tahun 1999. UU ini menyatakan bahwa pengadilan HAM dibentuk untuk mengadili pelanggaran HAM yang berat, seperti pembunuhan massal (genocide, pembunuhan sewenang-wenang atau diluar putusan pengadilan (arbitrary/ extra judicial killing), penyiksaan, penghilangan orang secara paksa, perbudakan atau diskriminasi yang dilakukan secara sistematis (systematic discrimination) yang sesuai dengan ketentuan Pasal 6 dan Pasal 7 rome statue of the international criminal court ${ }^{16}$.

15 Coba bandingkan pandangan ini dengan pendapat Bernard L. Tanya dalam POLITIK HUKUM :Agenda Kepentingan Bersama, yang menolak secara tegas penyamaan politk hukum dengan legal policy. Menurutnya legal policy contenya lebih memihak kepada kepentingan kepentigan parochial pihak atau golongan tertentu, sementara politik hukum lebih dari itu. Dia berbicara persoalan pencapaian tujuan bersama, Bernard L. Tanya, Politik Hukum :Agenda Kepentingan Bersama...,Op. Cit, hlm. 6.

16 Lihat penjelasan Pasal 104 ayat (1) Undang-Undang Nomor 39 Tahun 1999 dan penjelasan Pasal 7 UndangUndang Nomor 26 Tahun 2000 tentang Pengadilan $\mathrm{H}$
Salah satu konsekuensi diberlakukannya UU No. 39 Tahun 1999 tentang HAM ialah dibentuknya pengadilan HAM itu sendiri. Sebenarnya wacana terbentuknya pengadilan HAM telah lama muncul, akan tetapi dengan berbagai argument politis pemerintah, sampai pada implementasi UU No. 39 Than 1999 belum juga dibentuk. Namun seiring dengan menguatnya isu penegakan HAM, maka wacana tersebut semakin mengkristal dan tidak ada alasan lain bagi ppemerintah untuk membentuk pengadilan HAM. Pada akhirnya, Pemerintah mengeluarkan Peraturan Pemerintah Pengganti Undang-Undang (Perppu) Nomor 1 Tahun 1999 tentang Pengadilan HAM pada tanggal 8 Oktober 1999.

Apabila dilacak secara historis, pembentukan Perpu sesungguhnya dipersiapkan pemerintah dalam keadaan tergesa-gesa, yaitu sehubungan dengan terbentuknya opini umum, baik di dalam maupun di luar negeri. Di dalam negeri, dapat dilihat pada situasi politik dan sosial di masyarakat yang mendesak dan menghendaki pemerintah melalui pengadilan untuk segera mengadili pelaku-pelaku pelanggat HAM di berbagai daerah. Desakan dari luar negeri, maka dapat dijelaskan bahwa negara Indonesia sebagai bagian (state party) organisasi Perserikatan Bangsa-Bangsa (PBB) telah menjadi sorotan oleh masyarakat dunia internasional karena dinilai tidak mampu menyelesaikan problematika pelanggaran HAM yang terjadi. Oleh karena itu, apabila Indonesia tidak merespon desakan tersebut maka dapat menyudutkan posisi Indonesia dalam pergaulan antar bangsa ${ }^{17}$.

17 Yusril Ihza Mahendra, Mewujudkan Supremasi Hukum di Indonesia: Catatan dan Gagasan Prof. DR. Yusril Ihza Mahendra, (Jakarta: Departemen 
Berdasarkan uraian di atas, terlihat adanya tekanan dari dalam dan luar negara kepada Indonesia yang menjadi latar belakang utuk segera membentuk institusi judisial di bidang HAM. Adapun tugasnya, tidak lain adalah untuk memeriksa dan mengadili kasus-kasus yang terkait dengan pelanggaran atau kejahatan HAM yang terjadi di Indonesia,. Atas hal tersebut, maka dikeluarkannya Perppu sebagai solusi untuk memberikan kepadtian awal untuk memproses dan menyelesaikan pelangaran HAM. Potret ini jika dilihat dari aspek politik hukum, maka proses pembentukannya bertitik tolak atas perkembangan hukum masyarakat dalam negeri dan masyarakat global. Dengan kata lain, proses tersebut memiliki tendensi kepentingan nasional agar tetap eksis dalam percaturan dunia global. Apabila Indonesia tidak segera merespon situasi pada saat itu, dapat dipastikan Indonesia

Kehakiman dan HAM, Jakarta, 2001), hlm. 76 dan 88. Indonesia resmi menjadi anggota PBB ke-60, pada tanggal 28 September 1950. Hanya kurang dari setahun sejak pengakuan kedaulatan melalui Konferensi Meja Bundar, posisi Indonesia di dunia internasional terus menguat. Diplomat Indonesia yang ditunjuk menjadi Kepala Perwakilan Tetap pertama di PBB adalah L.N. Palar. Selama bergabung dengan PBB, prestasi Indonesia cukup istimewa. Indonesia tercatat telah mengirim tidak kurang dari 23 misi perdamaian melalui Kontingen Garuda, menjabat anggota tidak tetap Dewan Keamanan dua kali, ketua Komisi HAM PBB satu kali, dan rektor Universitas PBB satu kali. Lihat Indonesia Menjadi Anggota PBB ke-60, dalam

http://dunia.news.viva.co.id/news/rea $\mathrm{d} / 1119$

indonesia_menjadi_anggota_pbb_ke_60, dakses tanggal 28 Agustus 2015. yang telah mentasbihkan diri bergabung dengan PBB akan dikucilkan dalam pergaulan dunia. hal ini mengingat $\mathrm{PBB}$ secara tegas menjunjung nilai universal HAM dan berkomitmen menegakannya.

Sungguh pun demikian, masyarakat belum meras puas jika paying hukum pengadilan HAM hanya berdasarkan Peppu. Oleh karena itu masyarakat mendesak pemerintah untuk segera mengesahkan perppu menjadi Undang-Undang Nomor 26 Tahun 2000 tentang pengadilan HAM. Dengan demikian, pemberlakuan UU tersebut merupakan bagian dari program strategis pemerintah untuk menunjukan kepada masyarakat luas bahwa Indonesia dapat menyelesaikan persoalan pelanggaran HAM dengan sistem hukum nasional yang berlaku ${ }^{18}$. Hal tersebut merupakan kebijakan pemerintah nasional yang berasaskan nilai-nilai HAM.

Politik hukum HAM, merupakan kebijakan hukum (legal policy) tentang HAM yang mencakup kebijakan negara tentang bagaimana hukum tentang HAM itu telah dibuat. Bagaimana pula seharusnya hukum tentang HAM itu dibuat untuk membangun masa depan yang lebih baik, yakni kehidupan negar yang bersih dari pelanggaran-pelanggaran HAM terutama yang dilakukan oleh penguasa ${ }^{19}$. Artinya, pemerintah ketika hendak merumuskan atau membuat aturan HAM harus memiliki pertimbangan matang dan kioheren dengan situasi politik yang ada. Atas hal tersebut, maka dalam konteks UU

18 Lihat penjelasan umum UndangUndang Nomor 26 Tahun 2000 tentang Pengadilan HAM

19 Satya Arinanto, Hak Asasi Manusia dalam Transisi Politik di Indonesia, Cetakan Kedua, (Jakarta: Pusat Studi Hukum Tata Negara, 2005), hlm. 32 
No. 26 Tahun 2000, pertimbangan (politik hukum) lain pemerintah dalam pembentukannya adalah sebagai berikut :20

Merupakan perwujudan tanggung jawab bangsa Indonesia sebagai salah satu anggota Perserikatan BangsaBangsa. Dengan demikian, merupakan tanggung jawab moral dan hukum dalam menjunjung tinggi dan melaksanakan Deklarasi Universal HAM yang ditetapkan oleh PBB, serta yang terdapat dalam berbagai instrument hukum lainnya yang mengatur mengenai HAM yang telah dan/atau diterima oleh negara Republik Indonesia.

Dalam rangka melaksanakan TAP MPR No. XVII/MPR/1998 tentang HAM dan sebagai tindak lanjut dari UU No. 39 Tahun 1999 tentang HAM. Hal ini mengingat kebutuhan hukum yang sangat mendesakm, baik ditinjau dari kepentingan nasional maupun dari sisi kepentingan internasional maka segera dibentuk Pengadilan HAM yang berat.

Untuk mengatasi keadaan yang tidak menentu di bidang keamanan dan ketertiban umum, termasuk perekonomian nasional. Keberadaan Pengadilan HAM ini sekaligus diharapkan dapat mengembalikan kepercayaan masyarakat dan dunia internasional terhadap penegakan hukum dan jaminan kepastian hukum mengenai penegakan HAM di Indonesia.

20 Zainal Abidin, Pengadilan Hak Asasi Manusia di Indonesia...Op. Cit, hlm. 45. Perhatikan juga Keputusan Presiden tentang Pembentukan Pengadilan Hak Asasi Manusia Ad Hoc pada Pengadilan Negeri Jakarta Pusat, Keppres No. 53 Tahun 2001, Bagian Menimbang butir a.

\section{Kelemahan Undang - Undang Nomor 26 Tahun 2000 tentang Pengadilan Hak Asasi Manusia}

Dibentuknya UU No. 26 Tahun 2000, ialah dalam rangka agar tercapainya keadilan dalam proses penyelesaian permasalahan HAM di Indonesia. Namun semangat yang dibangun dari undang-undang tersebut, nampaknya tidak sejalan dengan faktanya. Hal ini tiodak dapat dilepaskan karena politik hukum pembentukannya yang cenderung sekedar memnuhi tuntutan berbagai pihak, juga karena terlalu limitasi waktu pembentukannya yang sangat singkat. Saperti yang kita ketahui, pembentukan undang-undang tersebut dibentuk ketika terungkapnya fakta telah terjadi pelanggaran HAM berat di Indonesia sehingga muncul desakan dari PBB untuk segera diadili pelaku-pelakunya. Mengingat waktu itu Indonesia belum memiliki intrumen hukum dan lembaganya, maka muncul gagasan dari PBB agar pelakunya diadili melalui pengadilan HAM Internasional atau Mahkamah Internasional.

Apabila hal itu terjadi, maka yuridiksi hukum nasional tidak digunakan dalam proses mengadili pelaku-pelakunya sehingga sebagai langkah antisipasi, pemerintah membentuk Perppu sebagai legitimasi pembentukan pengadilan HAM yang kemudian disahkan menjadi UU No. 26 Tahun 2000. Proses tersebut jelas sangat mendadak dan terburu-buru karena seolah-olah hanya dimaksudkan agar menghindarkan para pelaku pelanggaran HAM berat dari jerat Mahkamah Pidana Internasional ${ }^{21}$. Fakta itulah yang ke-

21 Pengadilan HAM di Indonesia Perlu Dibenahi

dalam:http://osdir.com/ml/culture.re gion.indonesia.ppi-india/2005-

03/msg00596.html, diakses tanggal 28 Agustus 2015 
mudian mengantarkan masih terdapat titik lemahg dalam undang-undang tersebut.

Kelemahan tersebut, misalnya dalam ketentuan Pasal 7 dan Pasal 9 UU No. 26 Tahun 2000 menjelaskan bahwa yang diakui sebagai pelanggaran HAM berat hanyalah pelanggaran terhadap hak-hak sipil dan tidak masuk dalam rumusan UU tersebut. Padahal apabila memperhatikan kebanyakan kasus-kasus pelanggaran HAM yang terjadi di Indonesia, umumnya dilatarbelakangi oleh pelanggaran terhadap hak-hak ekonomi, sosial dan budaya seperti perampasan tanahtanah masyarakat adat yang berujung penembakan terhadap masyarakat sipil atau pencemaran lingkungan yang dilakukan oleh perusahaan transnasional yang berujung penangkapan dan penyiksaan terhadap masyarakat sipil.

Potret di atas jelas sangat kontraproduktif dengan Kovenan Internasional tentang Hak-Hak Ekonomi, Sosial dan Budaya yang secara tegas melindungi kepemilikan HAM ekonomi, social dan budaya setiap orang ${ }^{22}$. Atas hal tersebut, maka pemerintah untuk tidak mengakui pelanggaran terhadap hak-hak ekonomi, sosial dan budaya sebagai pelanggaran HAM yang berat. Dalam konteks kekinian, mengingat Indonesia telah meratifikasi kovenan tersebut, maaka defines pelanggaran HAM yang berat sebagaimana diatur dalam pasal 7, 8 dan Pasal 8 UU No. 26 Tahun 2000 seharusnya dilakukan reviasi atau perubahan dengan memperluas definisi pelanggaran HAM yang

22 Kovenan tersebut, baru diartifikasi oleh Indonesia pada tahun 2005 melalui Undang-Undang Nomor 11 Tahun 2005. berat 23 . Dengan demikian, definisi pelanggaran HAM yang berat tidak hanya mencakup pelanggaran terhadap hakhak sipil dan politik, namun semua pelanggaran terhadap hak-hak ekonomi, sosial dan budaya juga harus diakui sebagai bagian dari pelanggaran HAM yang berat.

Kelemahan lain, ialah pembatasan terhadap tugas dan wewenang Komnas HAM yang hanya dapat melakukan penyelidikan terhadap kasus-kasus pelanggaran HAM yang berat sebagaimana diatur di dalam Pasal 18, Pasal 19 dan Pasal 20 UU No. 26 Tahun 200024 . Ketentuan tersebut, dalam praktiknya seringkali menjadikan hasil penyelidikan yang dilakukan oleh Komnas HAM dipatahkan oleh Kejaksaan Agung (Kejagung) yang di dalam undang-undang ini bertindak sebagai penyidik dan penuntut umum. Secara ketatanegaraan, Kejagung merupakan lembaga eksekutif sehingga potensi nir independensi demi menjaga kepentingan pemerintahan sangat kental. Oleh karena itu, hasil penyelidikan yang dilakukan oleh Komnas HAM sebagai lembaga independen jika dianggap bertentangan dengan kepentingan pemerintah akan dimentahkan oleh Kejagung.

Aspek lain titik lemah dalam UU No. 26 Tahun 2000, juga dapat dilihat pada uraian sebagai berikut : pertama, Pasal 9 dalam mengadopsi konsepsi 'Eidwspread or system attack directed against any civilian population' dalam Statuta Roma diterjemahkan keliru karena menjadi ditujukan secara

23 Romli Atmasasmita, Tafsir dan Penjelasan Undang-Undang Nomor 26 Tahun 2000 tentang Pengadilan HAM, dalam

http:/ / www.legalitas.org/?q=node/373, diakses pada tanggal 20 Mei 2013.

24 Ibid 
langsung kepada penduduk sipil 25. Padahal, seharusnya berbunyi ditujukan kepada populasi sipil. Kata "langsung" ini dapat berimplikasi pada seolah-olah hanya pelaku di lapangan yang dapat dikenakan pasal ini sedangkan pelaku di atasnya yang membuat kebijakan tidak tercakup dalam pasal ini. Istilah "penduduk" yang merupakan terjemahan dari kata "population", juga telah menyempitkan subyek hukum dengan menggunakan batasan-batasan wilayah. Hal itu, akan menyempitkan targe-target potensial korban kejahatan terhadap kemanusiaan yang hanya kepada warga negara dimana kejahatan tersebut berlangsung 26 .

Maksud hal di atas, ialah berkaitan erat dengan 'delik' tanggung jawab komando, sebagaimana yang diatur di dalam Pasal 42 ayat (1) yang menyatakan :

"Komandan Militer atau seseorang yang secara efektif bertindak sebagai komandan militer dapat dipertanggungjawabkan terhadap tindak pidana yang berada di dalam yurisdiksi Pengadilan HAM, yang dilakukan oleh pasukan yang berada di bawah komando dan pengendaliannya yang efektif atau dibawah kekuasaan dan pengendaliannya yang efektif dan tindak pidana tersebut merupakan akibat dari tidak dilakukan pengendalian pasukan secara patut..."

${ }^{25}$ Lihat Pasal 9 Undang-Undang Nomor26 tahun 2000 tentang Pengadilan Hak Asasi Manusia.

26 Zainal Abidin, Pengadilan Hak Asasi Manusia Di Indonesia....Op. Cit, hlm. 11. Lihat juga Human Rights Watch, Indonesia: Justice For East Timor Still Elusive, New York, 21 Februari 2002
Penggunaaan kata dapat dan bukannya kata akan atau harus, telah menyebabkan bahwa tanggung jawab komando dalam kasus pelanggaran HAM yang berat tidak bersifat wajib, tapi lebih dibebankan kepada pelaku langsung di lapangan (dalam hal ini para anak buah/prajurit dilapangan)

Kedua, pada Pasal 10 UU No. 26 Tahun 2000 secara eksplisit dinyatakan bahwa: "Dalam hal tidak ditentukan lain dalam undang-undang ini, hukum atas perkara pelanggaran HAM yang berat dilakukan berdasarkan ketentuan Hukum Acara Pidana". Hal itu berarti, hukum acara yang dipakai adalah sesuai Kitab Undang-Undang Hukum Acara Pidana (KUHAP) yang dalam banyak hal tidak sesuai standar praktek peradilan internasional. Sebagai contoh yang paling konkrit, soal alat bukti dimana di dalam KUHAP tidak memadai jika dikomparasikan dengan praktek-praktek peradilan internasional. Dalam praktek, peradilan internasional yang menyidangkan kasus pelanggaran HAM berat, justru lebih banyak memakai alat-alat bukti di luar yang diatur dalam KUHAP, seperti rekaman (film atau kaset yang berisi pidato), siaran pers, wawancara koran, wawancara pelaku, kliping koran, artikel lepas/opini. Sementara alat bukti yang sah menurut Pasal 184 KUHAP adalah keterangan saksi, keterangan ahli, surat, petunjuk dan keterangan terdakwa, yang seringkali sangat sulit untuk dilengkapi dengan minimal dua alat bukti yang sah ${ }^{27}$.

27 Budi Santoso, Evaluasi Kritis Atas Kelemahan UU Peradilan HAM, Makalah Disampaikan pada"Workshop Merumuskan Amandemen UndangUndang Peradilan HAM' yang diselenggarakan oleh PUSHAM UII, Yogyakarta, pada tanggal 26 Agustus 2003 
Sejatinya UU No. 26 Tahun 2000 sebagai salah satu buah reformasi yang sejak lama diperjuangkan, kehadirannya cukup membawa angin segar bagi upaya penegakan HAM di Tanah Air sekjaligus sebagai bukti dan upatya agar dapat masuk kategori bangsa yang dianggap menghormati HAM. Akan tetapi mengingat regulasi di bidang HAM yang telah ada kurang memperhatikan instrument internasional secara utuh maka belum berdampak baik bagi penegakan HAM. Akibatnya banyak kasus pelanggaran HAM di Indonesia yang tidak sampai ke meja pengadilan dan hanya menjadi bahan dokumentasi Komnas HAM. Atas potret yagn demikina, maka penting untuk dilakukan langkahlangkah penyelesaian terhadap mandulnya penegakan HAM di Indonesia.

\section{Langkah-langkah Hukum Yang dapat Dilakukan dalam Menegak- kan HAM di Indonesia Agar Berjalan Lebih Efektif}

Menyikapi ketidaksempurnaan dalam UU No. 26 Tahun 2000, tentunya diperlukan langkah-langkah konkrit dan sifatnya segera. Langkah yang dilakukan ialah dengan melakukan perubahan secara harmonis terhadap UU No. 26 Tahun 2000. Perubahan UU No. 26 Tahun 2000 harus diikuti dengan proses harnonisasi yang mengacu paa Statuta Roma dan Konvensi Internasional yang telah diratifikasi secara komprehensif, terutama mengenai perluasan definisi pelanggaran HAM yang berat serta perluasan fungsi Komnas HAM. Dewan Perwakilan Rakyat (DPR) dan Pemerintah, harus mengambil langkah cepat untuk melakukan perubahan secara komprehensif sehingga harnonisas terhadap UU No. 26 Tahun 2000.

Kerangka perubahan terhadap undang-undang tersebut, juga harus didasarkan pada pembuatan Hukum HAM responsif. Regulasi hukum responsive. Regulasi hukum responsive, akan selalu dikaitkan dengan tujuantujuan sosial yang melampaui narasi tekstual aturan. Nonet dan Selznick menyebutnya sebagai "the souvereignity of purpos" 28. Oleh karena itu, diperlukan proses partisipatif dalam pembuatannya dengan mensyaratkan dua hal ${ }^{29}$. Pertama, DPR dan Pemerintah harus meletakan dirinya sebagai kekuatan politik formal masyarakat, dan tidak memerankan diri sebagai konseptor undang-undang, apalagi memonopoli proses lahir hingga hingga evaluasi produk evaluasi produk perundang-undangan. Keduanya harus berperan sebagai kanal aspirasi kepentingan masyarakat, sehingga prosesnya harus bersifat buttom up bukan top down.

Kedua, organisasi masyarakat sipil harus dijadikan kekuatan intelektual yang mengkaji dan merumuskan kebutuhan hukum HAM masyarakat. Perpaduan DPR yang sejatinya adalah representasi politik dengan organisasi masyarakat sipil, diproyeksikan mampu merumuskan substansi hukum HAM yang memiliki kekuatan perlindungan (to protect), penghormatan (to respect) dan pemenuhan (to fulfill) HAM yang konstekstual dengan kebutuhan substansial masyarakat, bukan produk hukum yang sekedar responsive ter-

28 Philipe Nonet dan Philip Selznick, Law and Society in Transition : Toward Tanggapanive Law, (London; Harper and Row Publisher, 1974), dalam Bernard L. Tanya, dkk, Teori Hukum : Strategi Tertib Manusia Lintas Ruang dan Generasi, (Yogyakarta: Genta Publishing, 2010), hlm 204-204

29 Suparman Marzuki, Tragedi Politik Hukum HAM, (Yogyakarta: Pusham UII-Pustaka Pelajar, 2011), hlm 431432 
hadap demokrasi politik. Bagian penting dari prinsip partisipasi tersebut, adalah sifat afirmatif yang didelegasikan melalui peraturan perundangundangan sebagai respon atas kebutuhan riil masyarakat.

\section{PENUTUP}

Berdasarkan uraian di atas, maka dapat diambil beberapa kesimpulan, pertama, politik hukum pembentukan UU No. 26 Tahun 2000 mengenai pengadilan HAM merupakan upaya membangun hukum yang responsive, namun mengingat prosesnya masih dibarengi dengan bverbagai kepentingan maka produknya tidak seideal yang diharapkan dalam konteks kekinian. Selain itu, juga karena didasarkan pada pertimbangan adanya desakan dari masyarakat baik nasional maupun internasional. Atas proses politik hukum tersebut, maka pada kesimpulan kedua, dapat dijelaskan adanya dampak kelemahan terhadapo materi muatan UU No. 26 Tahun 2000 sehingga tidak efektif dalam implementasinya.

Guna mengurai permasalahan tersebut, maka pada kesimpulan ketiga penting untuk dilakukan perubahan secara komprehensif terhadap materi muatan UU No. 26 Tahun 2000. Perubahan tersebut, harus secara harmonis denga mengacu pada Statuta Roma dan Konvensi Internasional yang telah diratifikasi. Dalam rangka memantapkan proses perubahan, sehingga berdampak pada produk regulasi tyang baik maka proses perubahannya harus dilakukan dengan berpijak pada kerangka pembuatan hukum HAM yang responsif.

Adapun saran yang harus dilakukan, ialah DPR dan pemerintah harus menjadikan agenda khusus untuk melakukan perubahan secara harmonis dan komprehensif terhadap UU No. 26 Tahun 2000. Aspek harmonisasi dapat merujuk pada Konvensi Internasional yang telah diratifikasi oleh Indonesia. Selain itu, pemerintah harus segera meratifikasi Statuta Roma ke dalam saluran hukum nasional, terlebih Indonesia juga telag menjadi salah satu bagian (stqate party) penting dalam PBB.

\section{DAFTAR PUSTAKA}

\section{Buku-buku}

Abidin, Zainal, 2007, Pengadilan Hak Asasi Manusia Di Indonesia, Jakarta: Lembaga Studi dan Advokasi Masyarakat.

Arinanto, Satya, 2005, Hak Asasi Manusia dalam Transisi Politik di Indonesia, Cet. II, Jakarta: Pusat Studi Hukum Tata Negara.

Asshiddiqie, Jimly, 2006, Pengantar Ilmu Hukum Tata Negara. Jilid 1. Jakarta: Sekretariat Jenderal dan Kepaniteraan Mahakamah Konstitusi.

Bahar, Saafroedin, 2002, Konteks Kenegaraan Hak Asasi Manusia, Jakarta: Sinar Harapan.

MD., Moh. Mahfud, 1998, Politik Hukum di Indonesia, Cetakan Kedua, Jakarta: LP3ES.

1999, Pilar-pilar Demokrasi, Yogyakarta: Gama Media.

2010, Membangun Politik Hukum, Menegakkan Konstitusi, Jakarta: PT Raja Grafindo. 
Marzuki, Suparman, 2011, Tragedi Politik Hukum HAM, Yogyakarta: Pusham UII-Pustaka Pelajar.

Mahendra, Yusril Ihza, 2001, Mewujudkan Supremasi Hukum di Indonesia: Catatan dan Gagasan Prof. DR. Yusril Ihza Mahendra, Jakarta: Departemen Kehakiman dan HAM, Jakarta.

Nonet, Philipe dan Philip Selznick, 1974, Law and Society in Transition: Toward Tanggapanive Law, London; Harper and Row Publisher.

Pound, Roscoe, 1972, Pengantar Filsafat, Terjemahan Mohamad Radjab, Jakarta: Bharata.

Satjipto Rahardjo, 1985, Beberapa Pemikiran tentang Ancangan antar Disiplin dalam Pembinaan Hukum Nasional, Bandung: Sinar Baru.

1991, Imu Hukum, Bandung, Bandung: Citra Adtya Bhakti.

Soekamto, Soerjono, 1973, Pengantar Sosiologi Hukum, Jakarta: Bharata.

Syaukani, Imam dan A. Ahsin Thohari, 2006, Dasar-Dasar Politik Hukum, Jakarta: Raja Grafindo Persada.

Tanya, Bernard L., 2010, Teori Hukum: Strategi Tertib Manusia Lintas Ruang dan Generasi, Yogyakarta: Genta Publishing.

, 2011, Politik Hukum: Agenda Kepentingan Bersama, Yogyakarta: Genta Publishing.
Wahjono, Padmo, 1986, Indonesia Negara Berdasarkan atas Hukum, Jakarta: Ghalia Indonesia.

Wiyono, R., 2006, Pengadilan Hak Asasi Manusia Di Indonesia, Jakarta: Kencana Prenada Media Group.

Makalah dan Laporan Penelitian Human Rights Watch, Indonesia: Justice For East Timor Still Elusive, New York, 21 Februari 2002.

Mochtar, Akil, Ratifikasi Statuta Roma untuk Memperkuat Perlindungan Hak Asasi Manusia di Indonesia, Ceramah Kunci Hakim Konstitusi pada Seminar Nasional dalam Rangka World day of International Justice, diselenggarakan oleh ELSAM dan Komnas HAM, Jakarta 17 Juli 2012.

Nusantara, Abdul Hakim G., 1985, Politik Hukum Nasional, Makalah pada Karya Latihan Bantuan Hukum (Kalabahu), YLBHI \& LBH Surabaya, September 1985.

Progress Report Pemantauan Pengadilan HAM Ad Hoc, Jakarta: Elsam.

Santoso, Budi, Evaluasi Kritis Atas Kelemahan UU Peradilan HAM, Makalah Disampaikan pada "Workshop Merumuskan Amandemen Undang-Undang Peradilan HAM" yang diselenggarakan oleh PUSHAM UII, Yogyakarta, pada tanggal 26 Agustus 2003.

\section{Media}

Atmasasmita, Romli, Tafsir dan Penjelasan Undang-Undang Nomor 26 Tahun 2000 tentang 
Pengadilan HAM, dalam http://www.legalitas.org/?q=node /373. Akses 28 Januari 2019. Indonesia Menjadi Anggota PBB ke-60, dalam http://dunia.news.viva.co.id/new s/read/1119-

indonesia_menjadi_anggota_pbb_k e_60. Akses 28 Januari 2019.

Pengadilan HAM diIndonesia Perlu Dibenahi dalam http: / / osdir.com/ml/cult ure.region.indonesia.ppiindia/2005-03/msg00596.html. Akses 28 Januari 2019.

Komnas HAM: Lima Pelanggaran HAM Berat di Indonesia, http://www.tempointeraktif.com/ hg/nasional/2004/01/23/brk,20 040123-16,id.html, Akses 28 Januari 2019.

\section{Peraturan Perundang-Undangan Republik Indonesia.}

Undang-Undang Nomor 39 Tahun 1999 tentang Hak Asasi Manusia Republik Indonesia.

Undang-Undang Nomor 26 Tahun 2000 tentang Pengadilan Hak Asasi Manusia Republik Indonesia.

Ketetapan Majelis Permusyawaratan Rakyat Nomor XVII/MPR/1998 tentang Hak Asasi Manusia Republik Indonesia.

Keputusan Presiden Nomor 53 Tahun 2001 tentang Pembentukan Pengadilan Hak Asasi Manusia Ad Hoc pada Pengadilan Negeri Jakarta Pusat 